\title{
Framework on an On-Line Regulations Expert Permit Server
}

\author{
Semi-Annual Report \\ March 25 - September 24, 1997 \\ By:
Christine Hansen
}

Work Performed Under Contract No.: DE-FG22-96BC14948

\author{
For \\ U.S. Department of Energy \\ Office of Fossil Energy \\ Federal Energy Technology Center \\ P.O. Box 880 \\ Morgantown, West Virginia 26507-0880
}

By

Interstate Oil \& Gas Compact Commission (IOGCC)

900 Northeast 23rd Street

P. O. Box 53127

Oklahoma City, Oklahoma 73152-3127 


\section{Disclaimer}

This report was prepared as an account of work sponsored by an agency of the United States Government. Neither the United States Government nor any agency thereof, nor any of their employees, makes any warranty, express or implied, or assumes any legal liability or responsibility for the accuracy, completeness, or usefulness of any information, apparatus, product, or process disclosed, or represents that its use would not infringe privately owned rights. Reference herein to any specific commercial product, process, or service by trade

name, trademark, manufacturer, or otherwise does not necessarily constitute or imply its endorsement, recommendation, or favoring by the United States Government or any agency thereof. The views and opinions of authors expressed herein do not necessarily state or reflect those of the United States Government or any agency thereof. 
SEMI-ANNUAL TECHNICAL PROGRESS REPORT

FRAMEWORK ON AN ON-LINE REGULATIONS EXPERT PERMIT SERVER

DOE AWARD \# DE-FG22-96BC14948--02

(Reporting period March 25, 1997 through September 24, 1997)

Report Issued December 1997

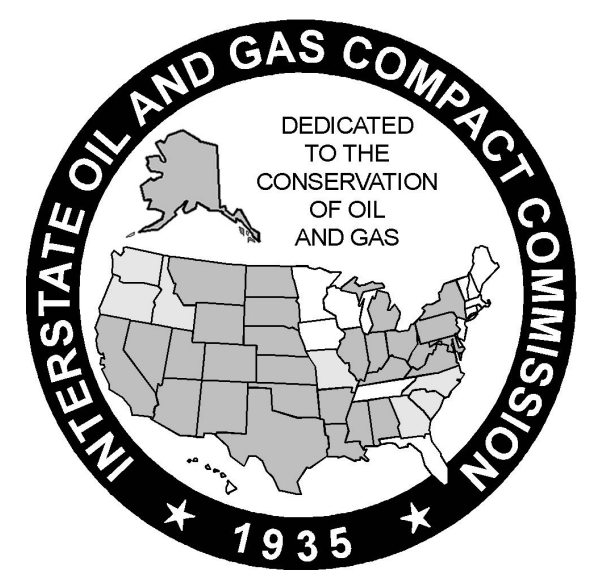

Submitted by:

Ms. Christine Hansen, Executive Director

Interstate Oil \& Gas Compact Commission (IOGCC)

900 Northeast 23rd Street

P.O. Box 53127

Oklahoma City, Oklahoma 73152-3127

Phone: (405)525-3556

Fax: (405)525-3592 


\section{Table of Contents}

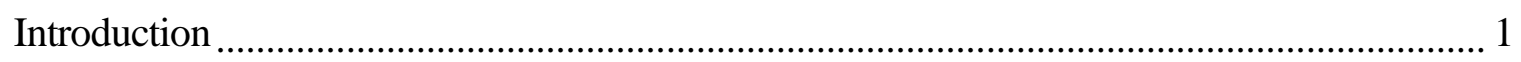

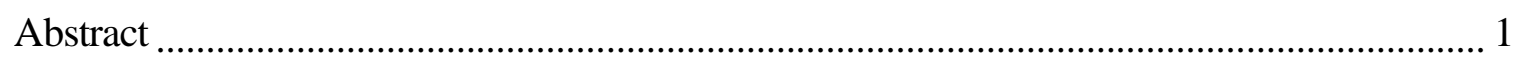

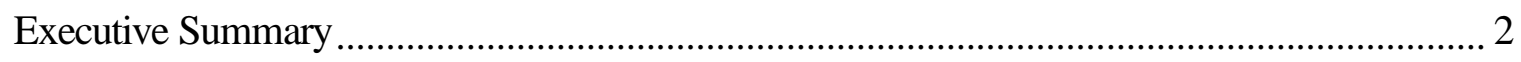

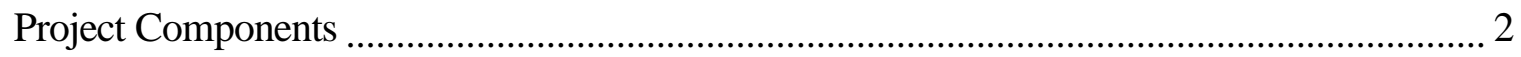

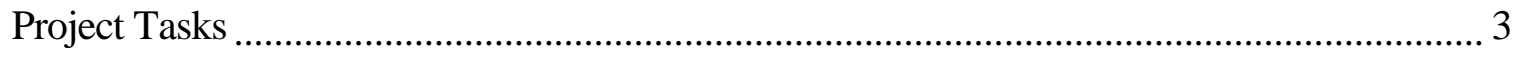

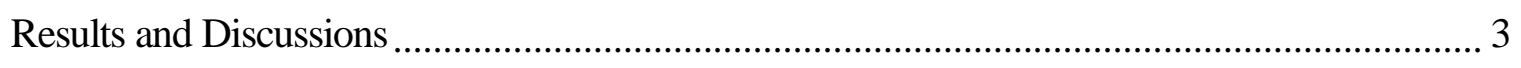

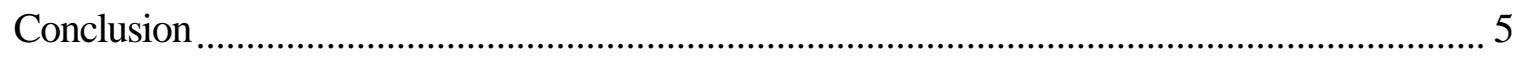

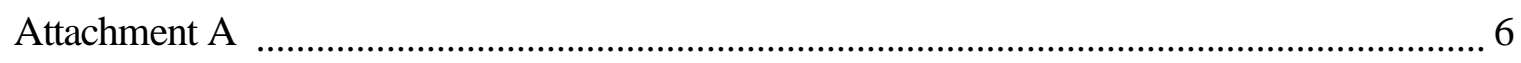

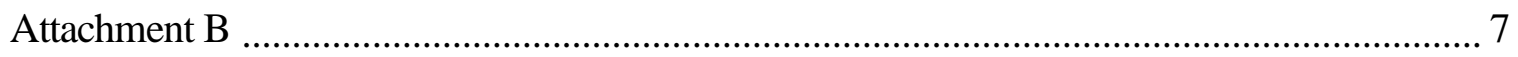




\title{
Semi-Annual Technical Report Framework of an On-line Permit Server
}

\section{$\underline{\text { Introduction }}$}

The Interstate Oil and Gas Compact Commission and it's member states have become increasingly concerned about environmental compliance costs for the petroleum exploration and production industry with estimated costs for 1990 at about $\$ 2$ billion. Over the last decade, these costs have increased at a rate of 3 to $5 \%$ per year. At a time when regulatory and environmental needs and costs are increasing, major oil companies are restructuring and reducing staffs. This places an increased burden on the remaining personnel charged with fulfilling regulatory compliance duties. As major oil producers have begun to concentrate on their more profitable overseas properties, they have created a greater role for the approximately 8000 independent oil and gas producers in the U.S. with many being small independent producers with limited staff. With small staffs, the independents lack the infrastructure to address an increasingly important aspect of production operations: compliance with environmental regulations. Depending on the level of industry activity, the oil and gas industry could incur an additional $\$ 16$ to $\$ 24$ billion in increased environmental compliance expenditures by the end of the 1990's. At current oil prices, the abandonment of remaining resources in known oil reservoirs could be accelerated by approximately ten years, and up to $30 \%$ of currently producing resources could be immediately abandoned because of increased regulations. Transferring new and innovative technologies to the industry can help defer reservoir abandonments, improve regulatory compliance, lower the costs of compliance, reduce risk, and help assure the development of new domestic resources.

\author{
$\underline{\text { Abstract }}$ \\ This eighteen month project involves the Interstate Oil and Gas Compact Commission (IOGCC) \\ and the oil and gas industry in a cooperative effort to use computer/communications \\ technology as a means of providing information from state agencies in a more effective \\ and simplified manner while allowing the oil and gas producers access to an on-line expert \\ system that will facilitate their compliance with state regulations. A major effort in the \\ project is the development of a framework for an on-line regulatory compliance and \\ permit server system. Other aspects of the project include providing feedback to state \\ regulatory agencies with recommendations suggesting where procedures or regulations \\ could be simplified or streamlined, identifying overlapping regulations, and surveying the \\ needs of the IOGCC states in the area of emerging issues where sharing of regulatory \\ procedures among the states might be helpful. The theme throughout the project is the \\ development of information systems that are transparent and easy to use and that provide \\ timely and effective access to information and technology. \\ This report summarizes progress achieved in the second six months of the project.
}




\section{$\underline{\text { Executive Summary }}$}

A key focus of the project is to develop the framework for an on-line expert system whereby oil and gas producers can use personal computers to find desired regulatory information in a simple and quick manner. The expert system is a hypertext Web-site on the Internet that was developed for rules and regulations pertaining to exploration and production activities in the petroleum industry. With a growing need for an understanding of regulations, the hypertext system is being designed to present the information desired by producers in an interactive and intuitive manner. The expert system is being developed from a producer's standpoint so that users are guided to the specific regulations applicable to their specific area of interest. Using a point-and-click system, guidance is provided on completion of the proper forms, reports, and notifications required to comply with applicable regulations. The example system will encompass a hypertext tutorial including necessary permit forms that will allow electronic filing in the future. There are also links between the system and the regulatory databases which will facilitate automatic updating if and when regulations change.

The example framework will illustrate the technological effectiveness and cost-savings achievable by an Internet-based system that the regulatory agencies in the IOGCC member states can consider implementing. Close coordination is provided between industry, state, and appropriate federal agencies and groups, and a project workgroup has been established. The framework is compatible with work being done on federal regulations, and a link is provided to DOE's new environmental compliance assistance system.

The objective of this project is to demonstrate the applicability of Internet communications technology as a means of providing information from state agencies in a more effective and simplified manner, while allowing oil and gas producers access to an on-line expert system that will assist them in complying with state regulations.

\section{Project Components}

The project involves: (1) developing the framework for an on-line regulatory permit server for oil and gas operations, (2) providing feedback to state regulatory agencies with recommendations suggesting where procedures or regulations could be simplified or streamlined, (3) identifying overlapping regulations, and (4) surveying the needs of the IOGCC states in the area of emerging issues where sharing of regulatory procedures among the states might be helpful. 


\section{Project Tasks}

To accomplish the project objectives, the following tasks were identified.

Task

Activity

1 Develop Framework for Regulatory Permit Server

2 Give Feedback to States on Simplifying Rules \& Regulations

3. Identify Overlapping Regulations

4 Survey States for Emerging Issues \& Concerns

Subtasks in Task 1 include: (1.1) install a Web server for the project, (1.2) survey the regulations databases of the IOGCC member states, (1.3) determine producer needs for the expert system/permit server, (1.4) implement a prototype regulations server for oil and gas operations and provide access to the server by a regional group of producers, (1.5) present producer needs for the system and demonstrate the framework to IOGCC member states, and (1.6) using input from IOGCC state organizations and the industry group, complete the design of the framework for the expert system/permit server.

\section{$\underline{\text { Results and Discussion }}$}

During the first six months of the project, all primary and lower-tier subcontracts were executed, and work began in each of the task areas. During the second six months of the project, several milestones were completed. Those being, the installation of a web server, documented producers needs for the expert system/permit server, several concept demonstrations were given to state regulators and industry, the system was beta-tested and is on-going. The system design was completed with feedback given to state agencies. Information was compiled on overlapping or duplication of regulations and guidelines for emerging issues.

The following discussion addresses the results obtained to date.

\section{Web Server}

A Web-server was designed that provides access to the framework for the permit server.

The framework is a hypertext document on the World Wide Web that oil and gas producers and others can access with personal computers. The server was developed from a producer's standpoint, but the system is designed to be compatible with efforts ongoing or planned at the state regulatory level. Built into the system for future use are the necessary permit forms that will allow 
electronic filing in the future. Also included are links between the system and the regulatory databases which will facilitate automatic updating when regulations change.

\section{Producer Needs}

Producer needs for a regulatory permit server were solicited from regional oil and gas operators and from several key trade associations. Many of the producers expressed the need for "one-stop shopping" where all of the relevant information is available. Presently, many producers are either unaware that information is available, or the desired information is located in several different places. Over the past three years, the petroleum industry has witnessed an explosion of information and data available on the Internet, and accessing this extensive and disparate information can be very difficult. Thus, the producers expressed the need to find the desired information in a simple and quick manner.

To address the needs of the potential users, the expert system is being developed from a producer's standpoint whereby users are guided to the specific regulations applicable to their specific area of interest. Using a point-and-click system, guidance is provided on completion of the proper forms, reports, and notifications required to comply with applicable regulations. The system will include a hypertext tutorial including necessary permit forms that can allow electronic filing in the future. There are also links between the system and the regulatory databases which will facilitate automatic updating if and when regulations change.

\section{Demonstration of Concept}

The permit server has been demonstrated to several area oil and gas producers, and the preliminary framework design was presented to the Strategic Technologies Council (STC) in March, 1997 during their annual business meeting in Washington, DC. In June 1997, a presentation on the project was given at the DOE Oil Technology Project Review meeting. In July 1997, the on-line server concept was demonstrated at the 1997 Rocky Mountain Symposium on Environmental Issues in Oil and Gas Operations in Golden, Colorado.

\section{On-line Server Workgroup}

An on-line server workgroup was appointed by Ms. Christine Hansen; members are Ted Streit, Chairman of the Workgroup and Chairman of the IOGCC Natural Resources Committee, William Guerard, Chairman of IOGCC Environmental Affairs Committee, William Daugherty, President of Daugherty Petroleum and Alternate IOGCC State Official from Kentucky, James Daniels, General Manager of Murfin Drilling Co. and Alternate IOGCC State Official from Kansas, and Troy Vickers, Amoco. The DOE representative on the workgroup is Rhonda Lindsey of the Bartlesville Project Office, and the IOGCC staff representative is Vicki Sensat. Members of the workgroup and several observers held their first meeting during the IOGCC annual meeting in December, 1996. DeLaine Perkins of the IOGCC discussed the background and overview of the project, Rhonda Lindsey gave DOE's perspective, and Dave Martin with Strategic Technology Resources provided a status and expectations of the project. The role of the work group was outlined, and several of the observers provided input regarding the project and related activities.At the IOGCC Spring Quarterly Meeting, the chairman of the workgroup met with key members of the project to review progress. An update on the on-line server project was given at the June 1997 IOGCC Midyear Meeting in Oklahoma City for the IOGCC Council of Regulatory Officials. Council members were 
asked to review the web document and offer feedback. The information will be used for modifications to the existing framework.

\section{Survey of Overlapping Regulations}

A total of fifteen individual interviews have been conducted concerning overlapping regulations in New Mexico, Colorado, Texas, and Coastal areas of Texas ( as opposed to offshore). These interviews have focused on overlapping regulations between municipalities and the State Oil \& Gas Regulatory agencies. In the case of the coastal areas of Texas, specifically the Laguana Madre Bay of South Padre Island, the multiple agency overlap consists of the Mineral Management service, U.S. Army Corp of Engineers, Coast Guard, EPA, State of Texas Parks and Wildlife, and the Texas Railroad Commission.

A generalized questionnaire was developed and distributed to the Oil \& Gas Regulatory agencies of the IOGCC member states. Approximately one-half of the member states have replied to the questionnaire. A copy of the final form of the questionnaire is attached (See Attachment A).

\section{Conclusion}

The response from the states suggests that the largest area of overlapping regulations exist between the BLM and the state agency. The states with the largest volume of oil and gas production responded that the areas of overlapping regulations are between the counties, and municipalities and the state agency. For example, the state of Arkansas has a major overlap battle between the Arkansas Public Service Commission and the Arkansas Oil and Gas Commission concerning the definition of oil and gas production pipelines in "non-rural" areas of Arkansas as "gathering or transmission lines" as described by the Natural Gas Pipeline Safety Act of 1968. This particular matter could have a widespread impact in other producing states with well sites located in "non-rural" areas. The IOGCC hopes to see more of this type of "problematic" situations identified and believes support of the web server can be more adequately justified as to its usefulness. 


\section{Attachment A}

\section{A REVIEW OF OVERLAPPING REGULATIONS ON THE OIL AND GAS INDUSTRY}

To fulfill the terms of a grant from the U.S. Department of Energy, the Interstate Oil and Gas Compact Commission (IOGCC) has commissioned a study of oil and gas industry regulations. The study will focus on overlapping regulations, where two or more government agencies have regulatory control over a particular aspect of the oil and gas industry. Historically, overlapping regulations were identified as existing between the state regulatory agencies and the federal regulatory agencies. However, there is increasing evidence of overlap between state agencies and native tribes, counties, or local municipalities. This study will survey the various regulatory agencies, with results incorporated into a final report. Your assistance in completing the attached brief questionnaire would be most appreciated.

\section{OVERLAPPING REGULATIONS SURVEY}

1.) Are you aware of any other government agencies, federal, state, tribal, county, or municipality which has imposed regulations on the oil and gas industry which overlap into the area of regulation previously handled by your agency? If yes, please give name of the agency and a person to contact with that agency.

2. Have any arrangements been made between your agency and the overlapping agency to facilitate ease of compliance with the overlapping regulations of both agencies? If yes, please explain or provide a contact whom we can interview for additional information.

3) Who in your organization should be contacted to discuss this problem of overlapping regulations and possible solutions to the problem?

Name:

Telephone:

Eax:

4. Would yoll and your agency be interested in receiving a copy of the report of this study for your review? If yes, please provide a mailing address for it to be sent.

Name:

Mailing Address:

City/St/Zip.

Thank yoll for your assistance, please fax this complete form to me, Rohert Blaylock, at (505)8355938 or by e-mail reb@baervan.nmt.edu 


\section{On-Line Server Document - Attachment B}

Table 1. Framework of an On-line Regulations Expert System/Permit Server

- $\quad$ Link to State Agency(ies)

- $\quad$ Rules, Regulations, \& Guidelines

-- Drilling Operations

-- Production Operations

-- Abandonment Procedures

-- Leaks, Spills, \& Releases

-- Water Quality \& Discharge

-- Air Quality \& Emissions

-- Pipeline Operations

-- Other Permitting Procedures

- $\quad$ Links to State Rules \& Regulations

- $\quad$ Link to DOE's Environmental Compliance Assistance System

- WWW Environmental Resources

-- State

-- Federal 


\section{Table 2. Suggested Components of State Link}

- Description of State Agency(ies)

- $\quad$ Overview of State Regulatory Programs

- Delegation of Authority

- $\quad$ Agency Function Chart

- $\quad$ Agency Directory

-- Mailing Address

-- Telephone and Fax Numbers

-- E-mail Addresses

- $\quad$ Map of Districts (Optional)

- $\quad$ Links to Rules \& Regulations

- $\quad$ Available Manuals \& Documents

- $\quad$ Related Information 